\title{
PENGARUH FINANCIAL KNOWLEDGE, FINANCIAL ATTITUDE DAN INTERNAL LOCUS OF CONTROL TERHADAP PERILAKU MANAJEMEN KEUANGAN
}

\author{
Nurul Rohmah ${ }^{1}$, Arik Susbiyani ${ }^{2}$, Rendy Mirwan Aspirandy ${ }^{3}$, Dwi Cahyono ${ }^{4}$ \\ 1,2,3,4 Universitas Muhammadiyah Jember, nururulau01@gmail.com
}

\begin{abstract}
ABSTRAK
Penelitian ini bertujuan untuk mengetahui apakah perilaku manajemen keuangan pada pelaku UMKM dapat diukur atau dipengaruhi dengan beberapa faktor yang telah diajukan dalam penelitian ini yaitu financial knowledge, financial attitude dan internal locus of control. Populasi dalam penelitian ini adalah UMKM dibidang pangan di Kecamatan Genteng, Kabupaten Banyuwangi dan sample dalam penelitian ini berjumlah 60 UMKM dibidang pangan Kecamatan Genteng, Kabupaten Banyuwangi yang diambil melalui metode purposive sampling. Berdasarkan hasil uji t, financial knowledge tidak memiliki pengaruh signifikan terhadap perilaku manajemen keuangan pada pelaku UMKM dibidang pangan Kecamatan Genteng, Kabupaten Banyuwangi. Pada faktor financial attitude dan internal locus of control memiliki pengaruh signifikan terhadap perilaku manajemen keuangan pada pelaku UMKM dibidang pangan Kecamatan Genteng, Kabupaten Banyuwangi. Hasil penelitian nantinya dapat dijadikan masukan serta referensi bagi objek penelitian untuk mengatasi hambatan atau masalah pada perilaku manajemen keuangan ketika mereka menjalankan usahanya.
\end{abstract}

Kata Kunci : Financial Knowledge, Financial Attitude, Internal Locus of Control, Perilaku Manajemen Keuangan

\begin{abstract}
This study aims to determine whether the behavior of financial management on MSME actors can be measured or influenced by several factors that have been proposed in this study, namely financial knowledge, financial attitude and internal locus of control. The population in this study were MSMEs in the food sector in Genteng District, Banyuwangi Regency and the sample in this study amounted to 60 MSMEs in the food sector, Genteng District, Banyuwangi Regency which were taken through purposive sampling method. Based on t test results, financial knowledge has no significant effect on the behavior of financial management in SMEs in the field of food District of tiles, Banyuwangi. The financial attitude and internal locus of control factors have a significant influence on the behavior of financial management on MSME actors in the food sector, Genteng District, Banyuwangi Regency. The results of the research can later be used as input an reference for the object of research to overcome obstacles or problems in financial management behavior when they run their business.
\end{abstract}

Keywords : Financial Knowledge, Financial Attitude, Internal locus of Control, Financial Management Behavior.

Naskah diterima : 19-03-2021 Naskah dipublikasikan: 31-03-2021 


\section{PENDAHULUAN \\ Latar Belakang}

Pada perkembangan ekonomi yang ada di Indonesia dapat dilihat untuk peningkatan yang terjadi memiliki korelasi dengan dunia industri. Terjadinya peningkatan pada kondisi perekonomian saat ini banyak memiliki dampak terhadap masyarakat, khususnya pada pelaku usaha mikro, kecil dan menengah. apabila dihubungkan ulang dengan keberadaan usaha mikro, kecil dan menengah yang ada di Indonesia saat ini, adanya usaha mikro, kecil dan menengah memberikan konstribusi paling banyak dalam peningkatan perekonomian yang terjadi. Usaha mikro, kecil dan menengah memberikan kosntribusi terbesarnya pada penyerapan tenaga kerja yang ada di Indonesia sebesar 90\% dan untuk konstribusi yang diberikan pada PDB Indonesia sudah lebih dari angka 50\% (Kompas.com, 2019).

Pada pemahaman bidang keuangan salah satu konsep dasar yang sering kali dianggap penting dan juga sering memiliki korelasi tinggi yaitu perilaku manajemen keuangan untuk setiap individu yang menjalankan usaha atau mendirikan usaha. Banyak pemahaman dan juga teori yang terkait dengan konsep ini, salah satunya teori dari (Mien, 2015) yang menyatakan teorinya terkait perilaku manajemen keuangan sebagai salah satu faktor dalam pengambilan keputusan, akuisisi usaha, alokasi anggaran keuangan dan juga pemanfaatan sumber daya keuangan bagi setiap usaha yang didirikan oleh semua individu. Beberapa permasalahan dan persoalan yang sering kali mendapatkan perhatian tersendiri bagi usaha mikro, kecil dan menengah dari perilaku manajemen keuangan yaitu pengetahuan keuangan (Yohana, 2010). Pemahaman dalam bidang keuangan merupakan salah satu ketrampilan yang harus dimiliki oleh setiap individu yang menjalankan usahanya, tingkat pemahaman keuangan nantinya akan dapat menjadi salah satu teknik tersendiri bagi setiap pelaku usaha dalam menyusun anggaran, mengambil keputusan maupun perencanaan jangka panjang (Yohana, 2010).

Persoalan lain yang sering kali mempengaruhi tingkat perilaku manajemen keuangan bagi pelaku usaha yaitu mengenai sikap keuangan yang ditanamkan dalam diri pelaku usaha itu sendiri. Pelaku usaha cenderung mengesampingkan sikap keuangan yang ditanamkan dalam diri selama menjalankan usahanya, sedangkan hal tersebut merupakan salah satu teknik dalam mengelola keuangan, serta motivasi dalam terus mengembangkan kemampuannya menjaga keberlangsungan usahanya (Kiryanto, 2000). Pelaku usaha selalu memerlukan motivasi dalam dirinya selama menjalankan usahanya, sehingga usaha yang dijalankannya dapat berkembang sesuai dengan selera pangsa pasar yang dituju (Kiryanto, 2000).

Pada permasalahan lain terkait dengan perilaku manajemen keuangan, yang menjadi faktor lainnya adalah Locus of Control. Locus of Control juga merupakan suatu cara dimana seorang individu memiliki tanggungjawab terhadap kegiatan yang akan terjadi di dalam kendali atau di luar kendali dirinya sendiri (Raharjono et al., 2012). Kecerdasan di bidang keuangan dalam kehidupan bermasyarakat yang lebih akrab dikenal dengan istilah kemelekan financial juga tak jarang pula kedua istilah tersebut dipertukarkan antara satu dengan yang lainnya (Raharjono et al., 2012).

Pertumbuhan UMKM di Kecamatan Genteng, Kabupaten Banyuwangi sendiri selalu mengalami kenaikan setiap tahunnya, sehingga keberadaan UMKM sendiri masih bisa dikatakan yang memberikan konstribusi paling besar. Namun, pada realitanya banyak UMKM yang tidak dapat menjaga keberlangsungana usahanya dan memenangkan persaingan kompetitif dengan para kompetitor. Pada akhirnya UMKM tersebut mengalami kebangkrutan dengan likuiditas yang masih harus dibayarkan kepada pihak lembaga jasa keuangan. Berdasarkan dari latar belakang yang telah diuraikan diatas, peneliti tertarik untuk melakukan penelitian yang serupa dengan 
menggunakan objek pelaku UMKM sentra pangan yang ada di Kecamatan Genteng, Kabupaten Banyuwangi. Penelitian ini akan meneliti beberapa faktor yang memiliki kemungkinan menjadi akibat dari perilaku manajemen keuangan yang diantaranya financial Knowledge, financial attitude dan internal locus of control.

\section{KAJIAN LITERATUR \\ Financial Knowledge}

Financial Knowledge merupakan segala sesuatu tentang keuangan yang terjadi atau sedang dialami oleh individu dalam kehidupan sehari-harinya (Norma et al., 2013). Financial Knowledge dapat juga dipahami dengan arti bahwa pengetahuan keuangan merupakan salah satu pemahaman yang dimiliki oleh setiap individu ats berbagai macam hal mengenai bidang keuangan, yang dalam bidang keuangan menjelaskan secara rinci terkait alat keuangan serta kemampuan dibidang keuangan (Andrew et al., 2014). Individu dalam memiliki financial knowledge yang baik maka perlu mengembangkan pula kemampuan keuangannya dan belajar mengenai kegunaan teknologi dibidang keuangan yang telah ada, teknologi keuangan sendiri adalah salah satu dari berbagai macam bentuk pengelolaan terhadap bidang keuangan mengambil suatu keputusan (Andrew et al., 2014).

Financial Knowledge merupakan dasar faktor yang kritis dalam seseorang mengambil keputusan dibidang keuangan (Iramani et al., 2013). Banyak orang yang menginginkan kehidupan yang sejahtera, yang berkualitas dan juga keamanan dalam hal keuangan. Keinginan tersebut dapat dicapai dan diwujudkan dengan pengelolaan pada keuangan yang baik dan benar. Pengelolaan keuangan yang baik dan benar juga harus disertai dengan financial knowledge yang tinggi yang dimilki oleh setiap individu. Pendekatan praktis untuk mewujudkan tujuan yang akan dicapai dalam financial knowledge yaitu melalui pencatatan dan penganggaran, perbankan dan penggunaan kredit, simpanan dan pinjaman, pembayaran pajak, membuat pengeluaran utama, membeli asuransi, investasi dan rencana pensiun (Iramani et al, 2013).

\section{Financial Attitude}

Financial attitude merupakan salah satu faktor yang memiliki kemungkinan memiliki pengaruh terhadap perilaku manajemen keuangan bagi pelaku usaha. Sikap sendiri memiliki arti suatu pernyataan dalam bentuk evaluative yang dapat dikatakan menyenangkan maupun tidak menyenangkan atas suatu obyek maupun peristiwa tertentu (Marsh, 2006). Sikap sendiri merupakan salah satu dari banyaknya pernyataan atas suatu obyek yang bersifat evaluative, baik yang memiliki kesan menyenangkan maupun tidak menyenangkan (Judge, 2015). Sikap memiliki 3 komponen yang terdiri dari :

a. Kognitif yaitu suatu pernyataan yang menyatakan opini atau pendapat atas sikap yang nantinya akan menentukan tingkah atas sesuatu atau sebagian yang memiliki kepentingan atas sikap tersebut.

b. Afektif (Perasaan) yaitu suatu pernyataan dalam bentuk emosional yang ada dalam diri setiap individu. Perasaan ini merupakan salah satu bentuk dari sikap yang banyak mempengaruhi setiap individu dalam aktivitas sehari-harinya yang membentuk perilaku tersendiri bagi setiap individu.

c. Perilaku atau tindakan yaitu bagian dari sikap yang memberikan gambaran dari individu tersebut dalam berperilaku terhadap individu lainnya.

Sikap sangat diperlukan oleh setiap individu dalam menjalankan aktivitasnya serta dalam segala hal yang mereka jalani dalam kehidupannya ini sikap sangat menentukan, tidak terkecuali dengan bidang keuangan (Judge, 2015). Sikap dalam bidang keuangan ini seringkali memberikan acuannya terhadap setiap individu agar selalu dapat merasakan permasalahan serta hambatan yang akan dihadapi nantinya terutama pada bidang keuangan, baik secara pribadi maupun untuk 
usahanya (Marsh, 2006). Setiap individu yang menjalankan kehidupan dengan memiliki tingkap sikap pada bidang keuangan yang baik akan membentuk pola pikir yang baik pula atas cara seseorang mengelola keuangannya, baik keuangan pribadi maupun keuangan yang mereka rancang dalam menjalankan usaha serta mengembangkan usahanya (Damanik, 2016).

\section{Internal Locus of Control}

Pengembangan Locus of Control individu dapat dipengaruhi oleh berbagai aspek didalamnya, baik yang disebabkan oleh lingkungan fisik maupun sosial. Lingkungan fisik yang pertama bagi seseorang merupakan keluarga (Rizkiawati, 2018). Pada keluarga inilah terjadi suatu interaksi antara orang tua dan anak, termasuk juga didalamnya penanaman nilai-nilai dan juga norma-norma yang akan diwarisi oleh seorang anak dari oran tuanya (Rizkiawati, 2018).

Apabila tingkah laku anak mendapatkan respon, maka anak akan merasakan sesuatu didalam lingkungannya, dengan kata lain anak tersebut akan merasakan sesuatu dalam pusat kendali lingkungan fisiknya, tingkat laku tersebut dapat menjadi salah satu yang akan dipelajari oleh anak tersebut. Sebaliknya, jika tingkah laku seorang anak tersebut tidak mendapat respon atau reaksi, maka anak akan merasa bahwa apa yang dia lakukan tidak mempunyai akibat apapun (Rizkiawati, 2018). Anak tidak kuasa menentukan akibatnya, keadaan diluar dirinya sendirilah yang nantinya akan menentukan. Sehingga hal tersebut dapat menimbulkan apa yang nantinya akan disebut sebagai Locus of Control eksternal (Setiyani et al., 2018).

\section{Perilaku Manajemen Keuangan}

Perilaku manajemen keuangan berkaitan dengan tanggungjawab bidang keuangan seseorang mengenai bagaimana cara mereka memanjemen keuangannya. Tanggungjawab tersebut merupakan salah satu proses dari mereka memanajemen keuangan mereka serta asset lainnya dengan cara yang dianggap lebih efektif (Yohana, 2010). Penganggaran ini digunakan dengan tujuan untuk memastikan secara lebih efektif bahwa setiap pelaku UMKM mampu mamanajemen kewajibannya dibidang finansial sesuai jangka waktu yang ditetapkan dengan menggunakan penghasilan yang sudah didapatkan dalam jangka waktu satu periode akuntansi yang sama (Yohana, 2010).

Pada pengalaman yang dimiliki oleh setiap tenaga kerja merupakan salah satu dari proses pembelajaran dalam hal memanajemen keuangan sehingga pada saat menghadapi permasalahan, tenaga kerja juga dapat mengambil keputusan yang lebih bijak lagi, sehingga semakin banyak pengalaman yang dimiliki maka akan semakin baik cara mereka mengambil keputusan (Yohana, 2010). Saving juga termasuk dari bagian pemasukan yang tidak dapat digunakan untuk anggaran belanja maupun dipergunakan untuk melakukan kegiatan atau aktivitas konsumsi untuk seharihari (Setiyani et al., 2018). Aktivitas seperti ini dapat diminimalkan resikonya dengan cara seseorang lebih memprioritaskan saving untuk melakukan penjagaan apabila dimasa yang akan datang seseorang tersebut membutuhkan dana cepat (Setiyani et al., 2018).

\section{HIPOTESIS}

Berdasarkan permasalahan yang ada dalam penelitian ini, maka hipotesis yang diajukan dalam penelitian ini memiliki hubungan terkait antar variabel. Sehingga hipotesis dalam penelitian ini dapat dituliskan sebagai berikut : 


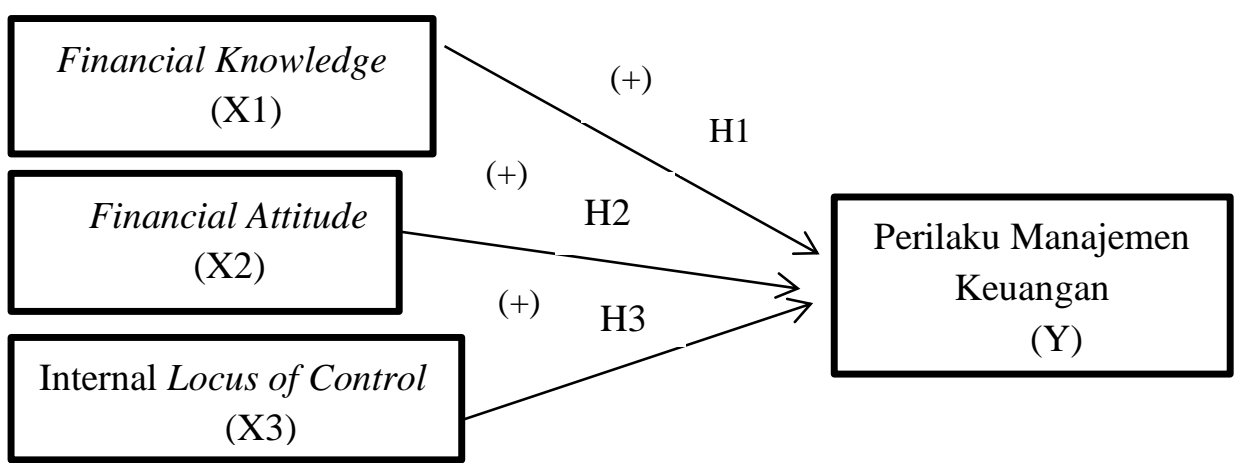

Gambar 1. Kerangka Konseptual

\section{METODE PENELITIAN}

\section{Desain Penelitian}

Jenis data dalam penelitian ini merupakan data kuantitatif yaitu perilaku manajemen keuangan pada pelaku UMKM. Untuk metode penelitian merupakan penelitian kausal-asosiatif atau penelitian yang mengarah pada sebab dan akibat. Data yang digunakan dalam penelitian ini adalah data primer. Data primer yang digunakan dalam penelitian ini merupakan UMKM bidang pangan yang ada di Kecamatan Genteng, Kabupaten Banyuwangi. Data diambil melalui survey, wawancara, kuiesioner dan observasi serta data dari BPS Kecamatan Genteng tahun 2019.

Penelitian ini menggunakan populasi pada pelaku UMKM bidang pangan yang ada di Kecamatan Genteng, Kabupaten Banyuwangi. Populasi dalam penelitian ini berjumlah 428 UMKM bidang pangan yang tercatat dalam BPS Kecamatan Genteng tahun 2019, sedangkan untuk sample berjumlah 60 UMKM bidang pangan yang diambil menggunakan metode purposive sampling dengan kriteria yang telah ditentukan oleh peneliti sebelumnya. Data dalam penelitian ini diolah dengan menggunakan aplikasi IBM SPSS 21. Pengujian dalam penelitian ini menggunakan analisis regresi berganda, uji normalitas, uji multikolinieritas, uji heteroskedasitisitas. Pengujian hipotesis menggunakan uji $\mathrm{f}$ untuk melihat pengaruh secara simultan dan juga uji t untuk melihat pengaruh variabel yang diajukan secara parsial. Model analisis regresi dalam penelitian ini dapat digambarkan sebagai berikut:

$$
\mathrm{Y}=\alpha+\beta 1 \mathrm{X} 1+\boldsymbol{\beta} 2 \mathrm{X} 2+\boldsymbol{\beta} 3 \mathrm{X} 3+\mathrm{e}
$$

Dimana :

Y : Perilaku Manajemen Keuangan

$\alpha \quad$ : Konstanta

$\beta 1,2,3$ : Koefisien regresi untuk variabel X1,X2 ,X3

$\mathrm{X} 1 \quad$ : Financial Knowledge

$\mathrm{X} 2$ : Financial Attitude

X3 : Internal Locus of Control

e : Faktor penggangu di luar model (kesalahan regresi), (Ghozali, 2013). 


\section{Definisi Operasional Variabel Penelitian}

Financial Knowledge (X1)

Pengetahuan keuangan atau financial knowledge adalah sesuatu yang memiliki keterkaitan atas kehidupan sehari-hari. Financial knowledge juga dapat dijelaskan sebagai salah satu bentuk pemahaman yang dimiliki oleh setiap individu atas banyak hal terkait bidang keuangan, yang terdiri dari financial tools dan financial skill. Indikator dalam variabel ini, yaitu general knowledge, saving and borrow, insurance dan investment. Hal ini sesuai dengan yang dijelaskan dalam penelitian (Yohana, 2010).

\section{Financial Attitude (X2)}

Sikap keuangan atau financial attitude merupakan keadaan pikiran, pendapat, serta penilaian tentang keuangan pribadi yang dapat diaplikasikan ke dalam sikap individu. Indikator dalam variabel ini, yaitu orientasi terhadap keuangan pribadi, filsafat hutang, menilai keuangan pribadi dan juga keamanan terkait keuangan. Hal tersebut sesuai dengan yang dijelaskan (Dwiastanti, 2017) dalam penelitiannya terkait financial attitude.

\section{Internal Locus of Control (X3)}

Locus of control memiliki keterkaitan dengan suatu keyakinan yang dimiliki oleh seseorang tentang nasib, keberuntungan dan juga takdir yang akan terjadi pada dirinya, apakah karena faktor internal atau juga karena faktor eksternal. Indikasi dalam internal locus of control, yaitu ability, interest dan effort. Hal tersebut sesuai dengan yang dijelaskan oleh (Arifin, 2017) dalam penelitiannya.

\section{Perilaku Manajemen Keuangan}

Perilaku manajemen keuangan merupakan perilaku seseorang dalam mengatur keuangan mereka dari sudut pandang psikologi dan juga dari kebiasaan individu. Indikator dalam perilaku manajemen keuangan, yaitu jenis-jenis perencanaan dan anggaran keuangan, teknik dalam menyusun perencanaan dan anggaran keuangan. Penjelasan ini sesuai dengan teori yang digunakan dalam penelitian (Yohana, 2010).

\section{HASIL DAN PEMBAHASAN}

\section{Gambaran Umum Objek Penelitian}

Kenaikan dan penurunan tingkat UMKM dipengaruhi oleh beberapa faktor dan juga aspek di dalamnya. Banyak UMKM dari berbagai bidang atau sentra yang mulai menunjukkan eksistensinya dan tak sedikit pula yang mulai redup ditengah perjalanan tanpa bisa menjaga keberlangsungan usahanya. Kenaikan dan penurunan yang paling jelas terlihat adalah pada UMKM di bidang industri pangan yang ada di Kecamatan Genteng, Kabupaten Banyuwangi. Umumnya, banyak UMKM di bidang industri pangan yang berdiri namun tidak dapat mempertahankan keberlangsungan usahanya dalam kurun waktu yang lama. Sedangkan dalam bidang industri lainnya UMKM yang berdiri cenderung lebih mampu mempertahankan keberlangsungan usahanya, seperti contohnya UMKM dibidang material.

Faktor-faktor yang diajukan terkait dengan perilaku manajemen keuangan pelaku UMKM dapat mempengaruhi pola pengelolaan setiap individu dalam menjalankan usahanya dan menjaga keberlangsungan usahanya. Hal-hal yang berpengaruh dapat dirasakan secara langsung oleh pelaku UMKM di bidang industri pangan dan juga tidak dapat dirasakan secara langsung oleh pelaku UMKM di bidang industri pangan Kecamatan Genteng, Kabupaten Banyuwangi. Sehingga pada penelitian ini peneliti menggunakan 30 UMKM di bidang industri pangan sebagai objek yang nantinya akan diteliti ada atau tidaknya pengaruh dari financial knowledge, financial 
attitude dan internal locus of control terhadap perilaku manajemen keuangan pada pelaku UMKM di bidang industri pangan yang ada di Kecamatan Genteng.

\section{Analisis Regresi Berganda}

Berdasarkan estimasi dari regresi linier berganda ini di lakukan dengan menggunakan program SPSS Versi 21,0 dan telah diperoleh hasil sebagai berikut:

Tabel 1. Analisis Regresi Berganda

\begin{tabular}{|l|l|c|l|}
\hline No & Variabel & Koefisisen Regresi & Signifikansi \\
\hline $\mathbf{1}$ & Konstanta & 2,717 & 0,281 \\
\hline $\mathbf{2}$ & Financial Knowledge (X1) & 0,058 & 0,555 \\
\hline $\mathbf{3}$ & Financial Attitude (X2) & 0,436 & 0,000 \\
\hline $\mathbf{4}$ & $\begin{array}{l}\text { Internal Locus of Control } \\
\text { (X3) }\end{array}$ & 0,402 & 0,000 \\
\hline
\end{tabular}

Berdasarkan tabel 4.12 dapat diketahui persamaan regresi yang terbentuk adalah:

$$
\mathrm{Y}=2,717+0,058 \mathrm{X} 1+0,436 \mathrm{X} 2+0,402 \mathrm{X} 3
$$

Berdasarkan persamaan tersebut dapat diartikan bahwa:

a. Konstanta $=2,717$. Hasil dari konstanta yang sudah diolah dari IBM SPSS versi 21.0 ini menunjukkan apabila secara keseluruhan variabel yang diajukan dalam penelitian ini secara bersamaan berada pada angka 0 , maka variabel terikat dalam penelitian ini memiliki nilai sebesar 2,717.

b. Koefisien regresi financial knowledge (X1) dari hasil pengujian analisis regresi yang sudah dilakukan memiliki arti bahwa variabel financial knowledge memiliki pengaruh positif serta signifikan terhadap variabel perilaku manajemen keuangan (Y).

c. Koefisien regresi financial attitude (X2) dari hasil pengujian analisis regresi yang sudah dilakukan memiliki arti bahwa variabel financial attitude memiliki pengaruh positif serta signifikan terhadap variabel perilaku manajemen keuangan (Y).

d. Koefisien regresi Internal locus of control (X3) dari hasil pengujian analisis regresi yang sudah dilakukan memiliki arti bahwa variabel internal locus of control memiliki pengaruh positif serta signifikan terhadap variabel perilaku manajemen keuangan $(\mathrm{Y})$.

\section{Uji Asumsi Klasik}

1. Uji Normalitas

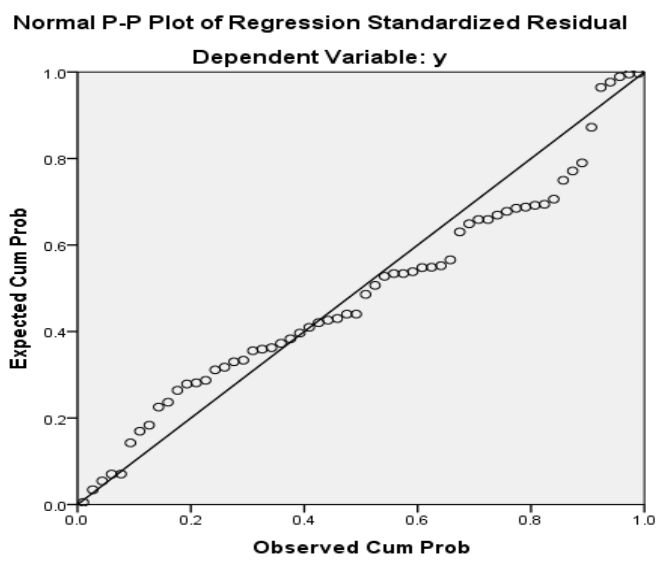

Gambar 2. Uji Normalitas 


\section{JURNAL EKOBIS: EKONOMI, BISNIS \& MANAJEMEN}

\section{Vol 11 Nomor 1 (2021)}

Setelah pengujian asumsi klasik uji normalitas sudah dilakukan serta hasil dari pengujian sudah dapat dibaca, maka dapat diketahui apakah data tersebut bebas dari normalitas atau tidak. Dapat dilihat pada gambar diatas apabila sebaran data tersebar atau terdistribusi secara normal, serta sebaran data yang ada pada gambar mengikuti garis diagonal. Sehingga menunjukkan hasil bahwa model regresi yang digunakan pada penelitian ini memenuhi syarat bebas dari uji asumsi klasik pengujian normalitas data.

2. Uji Multikolinieritas

Tabel 2. Uji Multikolinieritas

\begin{tabular}{|l|l|l|c|}
\hline No & Variabel & Nilai Tolerance & Nilai VIF \\
\hline $\mathbf{1}$ & Financial Knowledge & 0,679 & 1,472 \\
\hline $\mathbf{2}$ & Financial Attitude & 0,649 & 1,540 \\
\hline $\mathbf{3}$ & Internal Locus of Control & 0,890 & 1,124 \\
\hline
\end{tabular}

Berdasarkan tabel diatas telah memberikan gambaran apabila data dari penelitian ini memiliki nilai VIF yang dari semua variabel bebas yang diajukan pada penelitian ini memiliki hasil yang kurang dari atau lebih kecil dari 10, sedangkan untuk nilai toleransi yang dihasilkan dari pengujian data diatas menunjukkan hasil yang lebih besar dari nilai toleransi yang ditetapkan yaitu $10 \%$ atau sebesar 0,1 . Sehingga data variabel bebas dalam model regresi yang diajukan dalam penelitian ini bebas dari gejala multikolinieritas.

3. Uji Heterokedisitisitas

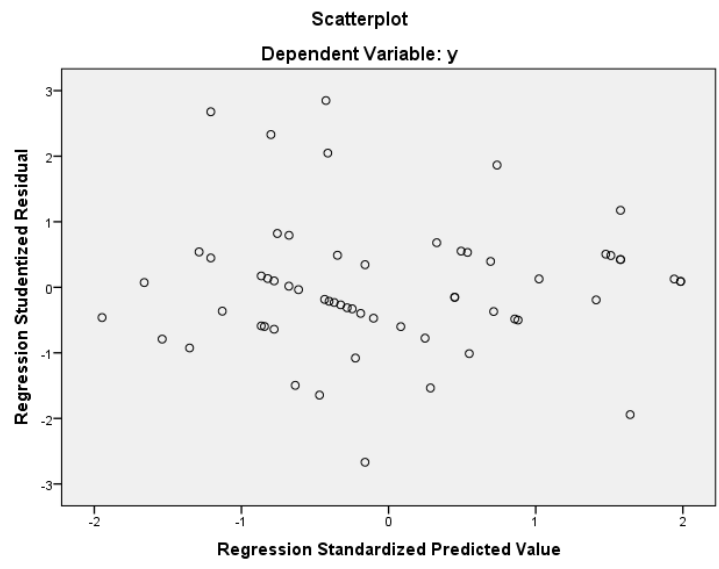

Gambar 3. Uji Heterokedastisitas

Pada hasil pengujian data dalam model regresi pada penelitian ini menunjukkan hasil seperti gambar diatas. Hasil pengujiannya dapat dikatakan bahwa model regresi yang diajukan dalam penelitian ini bebas dari gejala heterokedastisitas, yang berarti tidak terjadi penyimpangan pada pengujian asumsi klasik ini, dengan kata lain menerima hipotesis homoskedastisitas. Hasil pengujian diatas menunjukkan hasil bahwa sebaran titik-titik terjadi secara acak dan tidak membentuk suatu pola yang khusus dengan jelas serta tersebar dengan baik diatas maupun dibawah angka 0 pada sumbu $Y$. 


\section{Hasil Uji Hipotesis}

1. Uji t

Jika taraf signifikansi yang dihasilkan dari perhitungan pengujian dibawah 0,05 maka hipotesis diterima, sebaliknya jika taraf signifikansi hasil hitung lebih besar dari 0,05 maka hipotesis ditolak.

Tabel 3. Pengujian Hipotesis

\begin{tabular}{|l|l|l|l|l|l|l|}
\hline \multirow{2}{*}{ No } & \multirow{2}{*}{ Variabel } & \multicolumn{4}{|c|}{ Item Uji } & \multirow{2}{*}{\begin{tabular}{l} 
Ket \\
\cline { 3 - 6 }
\end{tabular}} \\
\cline { 3 - 6 } & Signifikansi & $\begin{array}{l}\text { Taraf } \\
\text { Signifikansi }\end{array}$ & $\begin{array}{l}\mathbf{t} \\
\text { hitung }\end{array}$ & tabel & \\
\hline $\mathbf{1}$ & Financial Knowledge & 0,555 & 0,05 & 0,594 & 2,003 & $\begin{array}{l}\text { Tidak } \\
\text { Signifikan }\end{array}$ \\
\hline $\mathbf{2}$ & Financial Attitude & 0,000 & 0,05 & 4,354 & 2,003 & Signifikan \\
\hline $\mathbf{3}$ & Internal Locus of Control & 0,000 & 0,05 & 4,946 & 2,003 & Signifikan \\
\hline
\end{tabular}

Berdasarkan data tabel diatas, dapat diketahui perbandingan antara taraf signifikansi dengan signifikansi tabel adalah sebagai berikut:

a. Dapat dilihat dari hasil uji hipotesis t yang sudah dapat dilihat dari tabel diatas, diketahui pengujian untuk financial knowledge yang memiliki signifikan hitung sebesar 0,555 yang lebih besar dari taraf signifikannya 0,05 . Sedangkan hasil pengujian untuk t hitungnya $(0,549)<\mathrm{t}$ tabel $(2,003)$ yang dapat dijelaskan bahwa hipotesis financial knowledge memiliki pengaruh terhadap perilaku manajemen keuangan ditolak. Sehingga dapat disimpulkan bahwa variabel financial knowledge tidak memiliki pengaruh terhadap perilaku manajemen keuangan pada pelaku UMKM dibidang pangan.

b. Hasil dari pengujian financial attitude mempunyai hasil signifikansi hitung sebesar 0,000 dan lebih kecil dari taraf signifikansi yaitu sebesar 0,05 . Untuk thitung $(4,354)>t$ tabel $(2,003)$ yang menunjukkan arti bahwa hipotesis financial attitude mempunyai pengaruh terhadap perilaku manajemen keuangan pelaku UMKM diterima. Hal ini menunjukkan arti bahwa financial attitude berpengaruh positif dan signifikan perilaku manajemen keuangan pada pelaku UMKM bidang pangan.

c. Sedangkan untuk hasil dari pengujian hipotesis yang terakhir untuk internal locus of control yang memiliki signifikan hitung 0,000 yang berarti lebih kecil dari taraf signifikan 0,000, sedangkan untuk $t$ hitung $(4,946)>$ dan untuk $t$ tabel $(2,003)$ yang dapat diartikan untuk hipotesis terakhir yaitu internal locus of control terhadap perilaku manajemen keuangan diterima. Artinya faktor dari internal locus of control berpengaruh positif dan signifikan terhadap perilaku manajemen keuangan pada pelaku UMKM bidang pangan.

\section{Koefisien Determinasi $\left(\mathbf{R}^{2}\right)$}

Berdasarkan hasil pengujian koefisien determinasi menggunakan aplikasi IBM SPSS 21.0 didapat hasil pengujian sebagai berikut:

Tabel 4. Koefisien Determinasi $\left(\mathrm{R}^{2}\right)$

\begin{tabular}{|l|l|c|}
\hline No & Kriteria & Koefisien \\
\hline $\mathbf{1}$ & $R$ & 0,753 \\
\hline $\mathbf{2}$ & R Square & 0,568 \\
\hline $\mathbf{3}$ & Adjusted $R$ Square & 0,544 \\
\hline
\end{tabular}

Hasil perhitungan regresi pada tabel 4 dapat diketahu bahwa koefisien determinasi yang diperoleh adalah sebesar 54,4\%. Hal ini menunjukkan bahwa 54,4\% variasi variabel perilaku 
manajemen keuangan dapat dijelaskan oleh variansi variabel financial knowledge, financial attitude dan internal locus of control. Sedangkan untuk sisa dari Adjusted $R$ Square sebesar 0,456 atau $45,6 \%$ dijelaskan oleh variabel lain yang tidak diajukan dalam penelitian ini misalnya kepribadian, income, dan lain sebagainya.

\section{Pembahasan}

Berdasarkan hasil pengujian hipotesis 1 diatas menunjukkan hasil bahwa $\mathrm{H} 1$ ditolak, yang berarti variabel financial knowledge tidak berpengaruh positif dan signifikan terhadap perilaku manajemen keuangan pelaku UMKM bidang pangan Kecamatan Genteng, Kabupaten Banyuwangi. Hasil penelitian ini sejalan dengan penelitian (Dwiastanti, 2017) bahwa financial knowledge memiliki pengaruh negatif dan signifikan terhadap perilaku manajemen keuangan atau secara singkat financial knowledge tidak mempengaruhi perilaku manajemen keuangan. Pada kecenderungan responden UMKM bidang pangan Kecamatan Genteng, Kabupaten Banyuwangi banyak yang memiliki tingkat pendidikan dan pemahaman bidang keuangan yang rendah. Banyak dari mereka yang menjalankan usahanya dengan tekad dan keinganan yang kuat, sehingga tingkat pendidikan dan pemahaman cenderung tidak mempengaruhi bagaimana mereka menentukan perilaku mereka atas manajemen keuangan mereka. Tingkat pendidikan dan pemahaman yang kurang dari bidang keuangan tidak mereka jadikan patokan untuk perilaku manajemen keuangan mereka dalam menjalankan usahanya.

Berdasarkan hasil pengujian hipotesis 2 diatas menunjukkan hasil bahwa $\mathrm{H} 2$ diterima, yang berarti variabel financial attitude berpengaruh positif dan signifikan terhadap perilaku manajemen keuangan pelaku UMKM bidang pangan Kecamatan Genteng, Kabupaten Banyuwangi. Hasil penelitian ini sejalan dengan penelitian sebelumnya yang dilakukan oleh (Humaira, 2018) yang menyatakan bahwa terdapat hubungan yang signifikan antara financial attitude seseorang akan cenderung memiliki perilaku manajemen keuangan yang lebih bijak. Pada kecenderungan responden UMKM bidang pangan Kecamatan Genteng, Kabupaten Banyuwangi banyak dari mereka yang cenderung memperbaiki sikap mereka terhadap pola pikir mereka memandang makna dari keuangan. Sehingga financial attitude dapat mengarahkan seorang dalam mengatur berbagai perilaku manajemen keuangannya dalam menjalankan usahanya maupun kehidupan sehari-harinya, dan nantinya dapat membantu dalam mengembangkan usahanya lebih baik lagi serta menjaga keberlangsungan usahanya dalam memenangkan persaingan kompetitif dengan para kompetitor.

Berdasarkan hasil pengujian hipotesis 3 diatas menunjukkan hasil bahwa hipotesis 3 diterima, yang berarti variabel internal locus of control berpengaruh positif dan signifikan terhadap perilaku manajemen keuangan pelaku UMKM bidang pangan Kecamatan Genteng, Kabupaten Banyuwangi. Penelitian ini menunjukkan hasil yang sejalan dengan penelitian sebelumnya yang dilakukan dengan (Iramani et al., 2013) yang menjelaskan bahwa semakin tinggi tingkat locus of control yang dimiliki oleh setiap individu maka memiliki kecenderungan akan mempengaruhi perilaku manajemen keuangan setiap pelaku UMKM akan semakin baik dan bertanggungjawab. Hal ini dapat dikatakan bahwa internal locus of control dapat selalu mempengaruhi individu tersebut akan rasa percaya diri untuk selalu meningkatkan usaha (effort yang dimiliki dalam proses untuk mewujudkan perilaku manajemen keuangan yang lebih bertanggungjawab. Penggunaan internal locus of control memungkinkan dapat membantu dalam mempengaruhi perilaku manajemen keuangan pelaku UMKM bidang pangan di Kecamatan Genteng, Kabupaten Banyuwangi dapat membantu pelaku UMKM tersebut dalam mengambil keputusan untuk setiap permasalahan yang berkaitan dengan usahanya. 


\section{PENUTUP \\ Simpulan}

Berdasarkan data analisis yang telah dilakukan dalam penelitian ini mengenai pengaruh financial knowledge, financial attitude dan internal locus of control terhadap perilaku manajemen keuangan pada pelaku UMKM bidang pangan yang ada di Kecamatan Genteng, Kabupaten Banyuwangi dengan menggunakan 60 sampel pada pelaku UMKM yang tersebar di 5 Desa pada Kecamatan Genteng, Kabupaten Banyuwangi. Hasil yang diperoleh dari pengujian 60 sampel adalah adanya pengaruh financial knowledge, financial attitude dan internal locus of control secara simultan dan signifikan terhadap perilaku manajemen keuangan pada pelaku UMKM yang ada di Kecamatan Genteng, Kabupaten Banyuwangi. Pengujian secara parsial menunjukkan hasil financial knowledge tidak memiliki pengaruh positif dan signifikan terhadap perilaku manajemen keuangan pada pelaku UMKM bidang pangan Kecamatan Genteng, Kabupaten Banyuwangi. Sedangkan untuk financial attitude dan internal locus of control memiliki pengaruh secara positif dan signifikan terhadap perilaku manajemen keuangan pada pelaku UMKM bidang pangan Kecamatan Genteng, Kabupaten Banyuwangi.

\section{Saran}

Hasil dari kesimpulan dalam penelitian, maka penulis merekomendasikan beberapa saransaran sebagai berikut: 1. Peneliti selanjutnya lebih memperhatikan jumlah sampel yang akan dijadikan objek dalam penelitian sehingga hasil dari penelitian lebih menggambarkan secara luas objek tersebut. 2. Pada peneliti selanjutnya diharapkan dapat menambah variabel-variabel yang diajukan dalam meakukan penelitian serupa terhadap perilaku manajemen keuangan. 


\section{REFERENSI}

Andrew, Vincentinus \& Nanik, L. (2014). Hubungan Faktor Demografi dan Pengetahuan Keuangan Dengan Perilaku Keuangan Karyawan Swasta di Surabaya. FINESTA, Vol. 02.

Asaff, R., Rahmayani, R., Artikel, I., Fakultas, A., \& Unanda, E. (2019). JEMMA | JURNAL OF ECONOMIC ,. 2(4), 9-22.

Damanik, L. A. dan H. I. (2016). Pengaruh Financial Attitude, Financial Knowledge, Parental Income Terhadap Financial Management Behavior. Jurnal Manajemen Teori Dan Terapan Tahun 9, No. 03.

Dwiastanti, A. (2017). Management and Business Review. 1(1), 1-8.

Ghozali, I. (2013). Aplikasi Analisis Multivariate Dengan Program SpSS Edisi Ketujuh. Badan Penerbit Universitas Diponegoro.

Iklima Humaira, E. M. S. (2018). Pengaruh Pengetahuan Keuangan, Sikap Keuangan dan Kepribadian terhadap Perilaku Manajemen Keuangan pada Pelaku UMKM Sentra Kerajinan Batik Kabupaten Bantul. Vol VII.

Judge, R. \&. (2015). Perilaku Organisasi, Konsep, Kontroversi, Aplikasi, Alih Bahasa. In Perilaku Organisasi (16th ed.). Salemba Empat.

Kholilah, N. Al, \& Iramani, R. (2013). Studi Financial Management Behavior Pada Masyarakat Surabaya. 3(1), 69-80.

Kiryanto. (2000). Pengaruh Persepsi Manajer Atas Informasi Akuntansi Keuangan Terhadap Keberhasilan Perusahaan Kecil. Simposium Nasional Akuntansi (SNA) Ke III.

Kompas.com. (2019). Peran UMKM dalam Perekonomian Indonesia. 20 Desember. https://www.kompas.com/skola/read/2019/12/20/120000469/peran-umkm-dalamperekonomian-indonesia?page $=$ all

Kuncoro, M. (2009). Metode Riset Untuk Bisnis \& Ekonomi Edisi 3 (Edisi 3). Erlangga.

Listiani, K. (2017). Pengaruh Financial Knowledge, Locus of Control Dan Financial Attitude Terhadap Financial Management.

Marsh, B. A. (2006). Examining The Personal Finance Attitudes, Behaviour, and Knowledge Levels of Fisrt-Year and Senior Student at Baptitst Universites In the State Of Texas. Disertasi.

Mien, T. (2015). Pengaruh Financial Attitude, Financial Knowledge, Parental Income Terhadap Financial Management Behavior. Jurnal Manajemen Teori Dan Terapan.

Rajna, A., Ezat, Sharifah W.P., Junaid, Syed Al, dan Moshiri, H. (2011). Financial Management Attitude and Practice Among the Medical Practitioners in Public and Private Medical Service in Malaysia. International Journal of Business and Management, Vol. 6, No, 105113.

Serly Novianti, A. R. T. dan E. D. (2016). Pengaruh Locus of Control, Financial Knowledge, Income Terhadap Financial Management Behavior. 24(September), 141-152.

Sugiyono. (2017). Metode Penelitian Kuantitaf, Kulialitatif dan R\&D. Alfabeta.

Wirjono, Endang Raino \& Raharjono, D. A. B. (2012). Survei Pemahaman dan Pemanfaatan Informasi Akuntansi dalam Usaha Kecil Menengah di Daerah Istimewa Yogyakarta. AUDI Jurnal Akuntansi Dan Bisnis, Vol 7 No 2.

Yohana, C. (2010). Pengaruh Locus of Control, Financial Knowledge , Income Terhadap Financial Management Behavior. 12(3), 131-144. 